\title{
Acid-sensing (proton-gated) ion channels (ASICs) in GtoPdb v.2021.3
}

\author{
Stephan Kellenberger ${ }^{1}$ and Lachlan D. Rash ${ }^{2}$ \\ 1. Université de Lausanne, Switzerland \\ 2. The University of Queensland, Australia
}

\begin{abstract}
Acid-sensing ion channels (ASICs, nomenclature as agreed by NC-IUPHAR [45, 2, 3]) are members of a Na${ }^{+}$channel superfamily that includes the epithelial $\mathrm{Na}^{+}$channel (ENaC), the FMRFamide activated channel (FaNaC) of invertebrates, the degenerins (DEG) of Caenorhabitis elegans, channels in Drosophila melanogaster and 'orphan' channels that include BLINaC [66] and INaC [68] that have also been named BASICs, for bile acid-activated ion channels [86]. ASIC subunits contain 2 TM domains and assemble as homo- or hetero-trimers [43, 40, 7, 90, 89, 73] to form proton-gated, voltage-insensitive, $\mathrm{Na}^{+}$permeable, channels that are activated by levels of acidosis occurring in both physiological and pathophysiological conditions with ASIC3 also playing a role in mechanosensation (reviewed in [42, 85, 45, 65, 23]). Splice variants of ASIC1 [termed ASIC1a (ASIC, $\mathrm{ASIC} \alpha, \mathrm{BNaC} 2 \alpha)$ [80], ASIC1b (ASIC $\beta, \mathrm{BNaC} 2 \beta$ ) [19] and ASIC1b2 (ASIC $\beta 2)$ [75]; note that ASIC1a is also permeable to $\mathrm{Ca}^{2+}$ ] and ASIC2 [termed ASIC2a (MDEG1, BNaC1 $\left.\alpha, \mathrm{BNC} 1 \alpha\right)$ [63, 81, 39] and ASIC2b (MDEG2, BNaC1ß) [53]] have been cloned and differ in the first third of the protein. Unlike ASIC2a (listed in table), heterologous expression of ASIC2b alone does not support $\mathrm{H}^{+}$-gated currents. A third member, ASIC3 (DRASIC, TNaC1) [79] is one of the most pH-sensitive isoforms (along with ASIC1a) and has the fastest activation and desensitisation kinetics, however can also carry small sustained currents. ASIC4 (SPASIC) evolved as a proton-sensitive channel but seems to have lost this function in mammals [55]. Mammalian ASIC4 does not support a proton-gated channel in heterologous expression systems but is reported to downregulate the expression of ASIC1a and ASIC3 [1, 41, 33, 51]. ASIC channels are primarily expressed in central (ASIC1a, $-2 \mathrm{a}, 2 \mathrm{~b}$ and -4 ) and peripheral neurons including nociceptors (ASIC1-3) where they participate in neuronal sensitivity to acidosis. They have also been detected in taste receptor cells (ASIC1-3)), photoreceptors and retinal cells (ASIC1-3), cochlear hair cells (ASIC1b), testis (hASIC3), pituitary gland (ASIC4), lung epithelial cells (ASIC1a and -3), urothelial cells, adipose cells (ASIC3), vascular smooth muscle cells (ASIC1-3), immune cells (ASIC1,-3 and -4) and bone (ASIC1-3) (ASIC distribution is well reviewed in [52, 27]). A neurotransmitter-like function of protons has been suggested, involving postsynaptically located ASICs of the CNS in functions such as learning and fear perception [34, 47, 93], responses to focal ischemia [87] and to axonal degeneration in autoimmune inflammation in a mouse model of multiple sclerosis [38], as well as seizures [94] and pain [85, 28, 29, 13, 31]. Heterologously expressed heteromultimers form ion channels with differences in kinetics, ion selectivity, pH- sensitivity and sensitivity to blockers that resemble some of the native proton activated currents recorded from neurones [53, 5, 37, 11]. In general, the known small molecule inhibitors of ASICs are non-selective or partially selective, whereas the venom peptide inhibitors have substantially higher selectivity and potency. Several clinically used drugs are known to inhibit ASICs, however they are generally more potent at other targets (e.g. amiloride at ENaCs, ibuprofen at COX enzymes) [64, 60]. The information in the tables below are for the effects of inhibitors on homomeric channels, for information of known effect on heteromeric channels see the comments below.
\end{abstract}

\section{Contents}

This is a citation summary for Acid-sensing (proton-gated) ion channels (ASICs) in the Guide to Pharmacology database (GtoPdb). It exists purely as an adjunct to the database to facilitate the recognition of citations to and from the database by citation analyzers. Readers will almost certainly want to visit the relevant sections of the database which are given here under database links. 
GtoPdb is a reference work which is most usefully represented as an on-line database. As in any publication this work should be appropriately cited, and the papers it cites should also be recognized. This document provides a citation for the relevant parts of the database, and also provides a reference list for the research cited by those parts. For further details see [15].

Please note that the database version for the citations given in GtoPdb are to the most recent preceding version in which the family or its subfamilies and targets were substantially changed. The links below are to the current version. If you need to consult the cited version, rather than the most recent version, please contact the GtoPdb curators.

\section{Database links}

Acid-sensing (proton-gated) ion channels (ASICs)

https://www.guidetopharmacology.org/GRAC/FamilyDisplayForward?familyId=118

Channels and Subunits

ASIC1

https://www.guidetopharmacology.org/GRAC/ObjectDisplayForward?objectId=684 ASIC2

https://www.guidetopharmacology.org/GRAC/ObjectDisplayForward?objectId=685 ASIC3

https://www.guidetopharmacology.org/GRAC/ObjectDisplayForward?objectId=686

\section{References}

1. Akopian AN, Chen CC, Ding Y, Cesare P and Wood JN. (2000) A new member of the acid-sensing ion channel family. Neuroreport 11: 2217-22 [PMID:10923674]

2. Alexander SP, Kelly E, Marrion N, Peters JA, Benson HE, Faccenda E, Pawson AJ, Sharman JL, Southan C and Davies JA et al.. (2015) The Concise Guide to PHARMACOLOGY 2015/16: Other ion channels. Br J Pharmacol 172: 5942-55 [PMID:26650442]

3. Alexander SP, Kelly E, Marrion NV, Peters JA, Faccenda E, Harding SD, Pawson AJ, Sharman JL, Southan C and Davies JA et al.. (2017) THE CONCISE GUIDE TO PHARMACOLOGY 2017/18: Other ion channels. Br J Pharmacol 174 Suppl 1: S195-S207 [PMID:29055039]

4. Andrey F, Tsintsadze T, Volkova T, Lozovaya N and Krishtal O. (2005) Acid sensing ionic channels: modulation by redox reagents. Biochim Biophys Acta 1745: 1-6 [PMID:16085050]

5. Babinski K, Catarsi S, Biagini G and Séguéla P. (2000) Mammalian ASIC2a and ASIC3 subunits co-assemble into heteromeric proton-gated channels sensitive to Gd3+. J Biol Chem 275: 2851925 [PMID:10842183]

6. Babinski K, Lê KT and Séguéla P. (1999) Molecular cloning and regional distribution of a human proton receptor subunit with biphasic functional properties. J Neurochem 72: 51-7 [PMID:9886053]

7. Baconguis I, Bohlen CJ, Goehring A, Julius D and Gouaux E. (2014) X-ray structure of acidsensing ion channel 1 -snake toxin complex reveals open state of a $\mathrm{Na}(+)$-selective channel. Cell 156: 717-29 [PMID:24507937]

8. Baron A, Diochot S, Salinas M, Deval E, Noël J and Lingueglia E. (2013) Venom toxins in the exploration of molecular, physiological and pathophysiological functions of acid-sensing ion channels. Toxicon 75: 187-204 [PMID:23624383]

9. Baron A and Lingueglia E. (2015) Pharmacology of acid-sensing ion channels - Physiological and therapeutical perspectives. Neuropharmacology 94: 19-35 [PMID:25613302]

10. Baron A, Schaefer L, Lingueglia E, Champigny G and Lazdunski M. (2001) Zn2+ and H+ are coactivators of acid-sensing ion channels. J Biol Chem 276: 35361-7 [PMID:11457851]

11. Baron A, Voilley N, Lazdunski M and Lingueglia E. (2008) Acid sensing ion channels in dorsal spinal cord neurons. J Neurosci 28: 1498-508 [PMID:18256271]

12. Blanchard MG, Rash LD and Kellenberger S. (2012) Inhibition of voltage-gated $\mathrm{Na}(+)$ currents in sensory neurones by the sea anemone toxin APETx2. Br J Pharmacol 165: 2167-77 [PMID:21943094]

13. Bohlen CJ, Chesler AT, Sharif-Naeini R, Medzihradszky KF, Zhou S, King D, Sánchez EE, Burlingame AL, Basbaum AI and Julius D. (2011) A heteromeric Texas coral snake toxin targets acid-sensing ion channels to produce pain. Nature 479: 410-4 [PMID:22094702]

14. Brunner FS, Anaya-Rojas JM, Matthews B and Eizaguirre C. (2017) Experimental evidence that parasites drive eco-evolutionary feedbacks. Proc Natl Acad Sci USA 114: 3678-3683 [PMID:28320947]

15. Buneman P, Christie G, Davies JA, Dimitrellou R, Harding SD, Pawson AJ, Sharman JL and Wu Y. (2020) Why data citation isn't working, and what to do about it Database 2020 [PMID:32367113]

16. Buta A, Maximyuk O, Kovalskyy D, Sukach V, Vovk M, Ievglevskyi O, Isaeva E, Isaev D, Savotchenko A and Krishtal O. (2015) Novel Potent Orthosteric Antagonist of ASIC1a Prevents 
NMDAR-Dependent LTP Induction. J Med Chem 58: 4449-61 [PMID:25974655]

17. Cadiou H, Studer M, Jones NG, Smith ES, Ballard A, McMahon SB and McNaughton PA. (2007) Modulation of acid-sensing ion channel activity by nitric oxide. J Neurosci 27: 13251-60 [PMID:18045919]

18. Chassagnon IR, McCarthy CA, Chin YK, Pineda SS, Keramidas A, Mobli M, Pham V, De Silva TM, Lynch JW and Widdop RE et al.. (2017) Potent neuroprotection after stroke afforded by a double-knot spider-venom peptide that inhibits acid-sensing ion channel 1a. Proc Natl Acad Sci USA 114: 3750-3755 [PMID:28320941]

19. Chen CC, England S, Akopian AN and Wood JN. (1998) A sensory neuron-specific, proton-gated ion channel. Proc Natl Acad Sci USA 95: 10240-5 [PMID:9707631]

20. Chen X, Kalbacher H and Gründer S. (2005) The tarantula toxin psalmotoxin 1 inhibits acidsensing ion channel (ASIC) 1a by increasing its apparent H+ affinity. J Gen Physiol 126: 71-9 [PMID:15955877]

21. Chen X, Kalbacher H and Gründer S. (2006) Interaction of acid-sensing ion channel (ASIC) 1 with the tarantula toxin psalmotoxin 1 is state dependent. J Gen Physiol 127: 267-76 [PMID:16505147]

22. Chen X, Qiu L, Li M, Dürrnagel S, Orser BA, Xiong ZG and MacDonald JF. (2010) Diarylamidines: high potency inhibitors of acid-sensing ion channels. Neuropharmacology $\mathbf{5 8}$ : 1045-53 [PMID:20114056]

23. Cheng YR, Jiang BY and Chen CC. (2018) Acid-sensing ion channels: dual function proteins for chemo-sensing and mechano-sensing. J Biomed Sci 25: 46 [PMID:29793480]

24. Chu XP, Close N, Saugstad JA and Xiong ZG. (2006) ASIC1a-specific modulation of acid-sensing ion channels in mouse cortical neurons by redox reagents. J Neurosci 26: 5329-39 [PMID:16707785]

25. Chu XP, Wemmie JA, Wang WZ, Zhu XM, Saugstad JA, Price MP, Simon RP and Xiong ZG. (2004) Subunit-dependent high-affinity zinc inhibition of acid-sensing ion channels. J Neurosci 24: 8678-89 [PMID:15470133]

26. de Weille JR, Bassilana F, Lazdunski M and Waldmann R. (1998) Identification, functional expression and chromosomal localisation of a sustained human proton-gated cation channel. FEBS Lett 433: 257-60 [PMID:9744806]

27. Deval E and Lingueglia E. (2015) Acid-Sensing Ion Channels and nociception in the peripheral and central nervous systems. Neuropharmacology 94: 49-57 [PMID:25724084]

28. Deval E, Noël J, Gasull X, Delaunay A, Alloui A, Friend V, Eschalier A, Lazdunski M and Lingueglia E. (2011) Acid-sensing ion channels in postoperative pain. J Neurosci 31: 6059-66 [PMID:21508231]

29. Deval E, Noël J, Lay N, Alloui A, Diochot S, Friend V, Jodar M, Lazdunski M and Lingueglia E. (2008) ASIC3, a sensor of acidic and primary inflammatory pain. EMBO J 27: 3047-55 [PMID:18923424]

30. Diochot S, Baron A, Rash LD, Deval E, Escoubas P, Scarzello S, Salinas M and Lazdunski M. (2004) A new sea anemone peptide, APETx2, inhibits ASIC3, a major acid-sensitive channel in sensory neurons. EMBO J 23: 1516-25 [PMID:15044953]

31. Diochot S, Baron A, Salinas M, Douguet D, Scarzello S, Dabert-Gay AS, Debayle D, Friend V, Alloui A and Lazdunski $\mathrm{M}$ et al.. (2012) Black mamba venom peptides target acid-sensing ion channels to abolish pain. Nature 490: 552-5 [PMID:23034652]

32. Diochot S, Salinas M, Baron A, Escoubas P and Lazdunski M. (2007) Peptides inhibitors of acidsensing ion channels. Toxicon 49: 271-84 [PMID:17113616]

33. Donier E, Rugiero F, Jacob C and Wood JN. (2008) Regulation of ASIC activity by ASIC4--new insights into ASIC channel function revealed by a yeast two-hybrid assay. Eur J Neurosci 28: 7486 [PMID:18662336]

34. Du J, Reznikov LR, Price MP, Zha XM, Lu Y, Moninger TO, Wemmie JA and Welsh MJ. (2014) Protons are a neurotransmitter that regulates synaptic plasticity in the lateral amygdala. Proc Natl Acad Sci USA 111: 8961-6 [PMID:24889629]

35. Dubé GR, Lehto SG, Breese NM, Baker SJ, Wang X, Matulenko MA, Honoré P, Stewart AO, Moreland RB and Brioni JD. (2005) Electrophysiological and in vivo characterization of A317567, a novel blocker of acid sensing ion channels. Pain 117: 88-96 [PMID:16061325]

36. Er SY, Cristofori-Armstrong B, Escoubas P and Rash LD. (2017) Discovery and molecular interaction studies of a highly stable, tarantula peptide modulator of acid-sensing ion channel 1. Neuropharmacology 127: 185-195 [PMID:28327374]

37. Escoubas P, De Weille JR, Lecoq A, Diochot S, Waldmann R, Champigny G, Moinier D, Ménez A and Lazdunski M. (2000) Isolation of a tarantula toxin specific for a class of proton-gated $\mathrm{Na}+$ channels. J Biol Chem 275: 25116-21 [PMID:10829030]

38. Friese MA, Craner MJ, Etzensperger R, Vergo S, Wemmie JA, Welsh MJ, Vincent A and Fugger L. (2007) Acid-sensing ion channel-1 contributes to axonal degeneration in autoimmune inflammation of the central nervous system. Nat Med 13: 1483-9 [PMID:17994101]

39. García-Añoveros J, Derfler B, Neville-Golden J, Hyman BT and Corey DP. (1997) BNaC1 and 
$\mathrm{BNaC} 2$ constitute a new family of human neuronal sodium channels related to degenerins and epithelial sodium channels. Proc Natl Acad Sci USA 94: 1459-64 [PMID:9037075]

40. Gonzales EB, Kawate T and Gouaux E. (2009) Pore architecture and ion sites in acid-sensing ion channels and P2X receptors. Nature 460: 599-604 [PMID:19641589]

41. Gründer S, Geissler HS, Bässler EL and Ruppersberg JP. (2000) A new member of acid-sensing ion channels from pituitary gland. Neuroreport 11: 1607-11 [PMID:10852210]

42. Gründer S and Pusch M. (2015) Biophysical properties of acid-sensing ion channels (ASICs). Neuropharmacology 94: 9-18 [PMID:25585135]

43. Jasti J, Furukawa H, Gonzales EB and Gouaux E. (2007) Structure of acid-sensing ion channel 1 at 1.9 A resolution and low pH. Nature 449: 316-23 [PMID:17882215]

44. Jiang Q, Papasian CJ, Wang JQ, Xiong ZG and Chu XP. (2010) Inhibitory regulation of acidsensing ion channel 3 by zinc. Neuroscience 169: 574-83 [PMID:20580786]

45. Kellenberger S and Schild L. (2015) International Union of Basic and Clinical Pharmacology. XCI. structure, function, and pharmacology of acid-sensing ion channels and the epithelial $\mathrm{Na}+$ channel. Pharmacol Rev 67: 1-35 [PMID:25287517]

46. Krauson AJ, Rooney JG and Carattino MD. (2018) Molecular basis of inhibition of acid sensing ion channel 1A by diminazene. PLoS One 13: e0196894 [PMID:29782492]

47. Kreple CJ, Lu Y, Taugher RJ, Schwager-Gutman AL, Du J, Stump M, Wang Y, Ghobbeh A, Fan R and Cosme CV et al.. (2014) Acid-sensing ion channels contribute to synaptic transmission and inhibit cocaine-evoked plasticity. Nat Neurosci 17: 1083-91 [PMID:24952644]

48. Kuduk SD, Di Marco CN, Bodmer-Narkevitch V, Cook SP, Cato MJ, Jovanovska A, Urban MO, Leitl M, Sain N and Liang A et al.. (2010) Synthesis, structure-activity relationship, and pharmacological profile of analogs of the ASIC-3 inhibitor A-317567. ACS Chem Neurosci 1: 1924 [PMID:22778804]

49. Lee JYP, Saez NJ, Cristofori-Armstrong B, Anangi R, King GF, Smith MT and Rash LD. (2018) Inhibition of acid-sensing ion channels by diminazene and APETx2 evoke partial and highly variable antihyperalgesia in a rat model of inflammatory pain. Br J Pharmacol 175: 2204-2218 [PMID:29134638]

50. Li WG, Yu Y, Zhang ZD, Cao H and Xu TL. (2010) ASIC3 channels integrate agmatine and multiple inflammatory signals through the nonproton ligand sensing domain. Mol Pain 6: 88 [PMID:21143836]

51. Lin SH, Chien YC, Chiang WW, Liu YZ, Lien CC and Chen CC. (2015) Genetic mapping of ASIC4 and contrasting phenotype to ASIC1a in modulating innate fear and anxiety. Eur J Neurosci 41: 1553-68 [PMID:25828470]

52. Lin SH, Sun WH and Chen CC. (2015) Genetic exploration of the role of acid-sensing ion channels. Neuropharmacology 94: 99-118 [PMID:25582292]

53. Lingueglia E, de Weille JR, Bassilana F, Heurteaux C, Sakai H, Waldmann R and Lazdunski M. (1997) A modulatory subunit of acid sensing ion channels in brain and dorsal root ganglion cells. J Biol Chem 272: 29778-83 [PMID:9368048]

54. Liu Y, Ma J, DesJarlais RL, Hagan R, Rech J, Lin D, Liu C, Miller R, Schoellerman J and Luo J et al.. (2021) Molecular mechanism and structural basis of small-molecule modulation of the gating of acid-sensing ion channel 1. Commun Biol 4: 174 [PMID:33564124]

55. Lynagh T, Mikhaleva Y, Colding JM, Glover JC and Pless SA. (2018) Acid-sensing ion channels emerged over 600 Mya and are conserved throughout the deuterostomes. Proc Natl Acad Sci U $S$ A 115: 8430-8435 [PMID:30061402]

56. Lynagh T, Romero-Rojo JL, Lund C and Pless SA. (2017) Molecular Basis for Allosteric Inhibition of Acid-Sensing Ion Channel 1a by Ibuprofen. J Med Chem 60: 8192-8200 [PMID:28949138]

57. Mamet J, Baron A, Lazdunski M and Voilley N. (2002) Proinflammatory mediators, stimulators of sensory neuron excitability via the expression of acid-sensing ion channels. J Neurosci 22: 10662-70 [PMID:12486159]

58. Marra S, Ferru-Clément R, Breuil V, Delaunay A, Christin M, Friend V, Sebille S, Cognard C, Ferreira T and Roux C et al.. (2016) Non-acidic activation of pain-related Acid-Sensing Ion Channel 3 by lipids. EMBO J 35: 414-28 [PMID:26772186]

59. Munro G, Christensen JK, Erichsen HK, Dyhring T, Demnitz J, Dam E and Ahring PK. (2016) NS383 Selectively Inhibits Acid-Sensing Ion Channels Containing 1a and 3 Subunits to Reverse Inflammatory and Neuropathic Hyperalgesia in Rats. CNS Neurosci Ther 22: 135-45 [PMID:26663905]

60. Osmakov DI, Khasanov TA, Andreev YA, Lyukmanova EN and Kozlov SA. (2020) Animal, Herb, and Microbial Toxins for Structural and Pharmacological Study of Acid-Sensing Ion Channels. Front Pharmacol 11: 991 [PMID:32733241]

61. Osmakov DI, Kozlov SA, Andreev YA, Koshelev SG, Sanamyan NP, Sanamyan KE, Dyachenko IA, Bondarenko DA, Murashev AN and Mineev KS et al.. (2013) Sea anemone peptide with uncommon $\beta$-hairpin structure inhibits acid-sensing ion channel 3 (ASIC3) and reveals analgesic activity. J Biol Chem 288: 23116-27 [PMID:23801332]

62. Peigneur S, Béress L, Möller C, Marí F, Forssmann WG and Tytgat J. (2012) A natural point 
mutation changes both target selectivity and mechanism of action of sea anemone toxins. FASEB J 26: 5141-51 [PMID:22972919]

63. Price MP, Snyder PM and Welsh MJ. (1996) Cloning and expression of a novel human brain Na+ channel. J Biol Chem 271: 7879-82 [PMID:8626462]

64. Rash LD. (2017) Acid-Sensing Ion Channel Pharmacology, Past, Present, and Future .... Adv Pharmacol 79: 35-66 [PMID:28528673]

65. Rook ML, Musgaard M and MacLean DM. (2021) Coupling structure with function in acidsensing ion channels: challenges in pursuit of proton sensors. J Physiol 599: 417-430 [PMID:32306405]

66. Sakai H, Lingueglia E, Champigny G, Mattei MG and Lazdunski M. (1999) Cloning and functional expression of a novel degenerin-like Na+ channel gene in mammals. J Physiol (Lond.) 519 Pt 2: 323-33 [PMID:10457052]

67. Salinas M, Rash LD, Baron A, Lambeau G, Escoubas P and Lazdunski M. (2006) The receptor site of the spider toxin PcTx1 on the proton-gated cation channel ASIC1a. J Physiol 570: 339-54 [PMID:16284080]

68. Schaefer L, Sakai H, Mattei M, Lazdunski M and Lingueglia E. (2000) Molecular cloning, functional expression and chromosomal localization of an amiloride-sensitive $\mathrm{Na}(+)$ channel from human small intestine. FEBS Lett 471: 205-10 [PMID:10767424]

69. Schmidt A, Rossetti G, Joussen S and Gründer S. (2017) Diminazene Is a Slow Pore Blocker of Acid-Sensing Ion Channel 1a (ASIC1a). Mol Pharmacol 92: 665-675 [PMID:29025967]

70. Sherwood TW, Lee KG, Gormley MG and Askwith CC. (2011) Heteromeric acid-sensing ion channels (ASICs) composed of ASIC2b and ASIC1a display novel channel properties and contribute to acidosis-induced neuronal death. J Neurosci 31: 9723-34 [PMID:21715637]

71. Smith ES, Cadiou H and McNaughton PA. (2007) Arachidonic acid potentiates acid-sensing ion channels in rat sensory neurons by a direct action. Neuroscience 145: 686-98 [PMID:17258862]

72. Staruschenko A, Dorofeeva NA, Bolshakov KV and Stockand JD. (2007) Subunit-dependent cadmium and nickel inhibition of acid-sensing ion channels. Dev Neurobiol 67: 97-107 [PMID:17443775]

73. Sun D, Liu S, Li S, Zhang M, Yang F, Wen M, Shi P, Wang T, Pan M and Chang S et al.. (2020) Structural insights into human acid-sensing ion channel 1a inhibition by snake toxin mambalgin1. Elife 9 [PMID:32915133]

74. Ugawa S, Ishida Y, Ueda T, Inoue K, Nagao M and Shimada S. (2007) Nafamostat mesilate reversibly blocks acid-sensing ion channel currents. Biochem Biophys Res Commun 363: 203-8 [PMID:17826743]

75. Ugawa S, Ueda T, Takahashi E, Hirabayashi Y, Yoneda T, Komai S and Shimada S. (2001) Cloning and functional expression of ASIC-beta2, a splice variant of ASIC-beta. Neuroreport 12: 2865-9 [PMID:11588592]

76. Vick JS and Askwith CC. (2015) ASICs and neuropeptides. Neuropharmacology 94: 36-41 [PMID:25592215]

77. Voilley N, de Weille J, Mamet J and Lazdunski M. (2001) Nonsteroid anti-inflammatory drugs inhibit both the activity and the inflammation-induced expression of acid-sensing ion channels in nociceptors. J Neurosci 21: 8026-33 [PMID:11588175]

78. Vukicevic M, Weder G, Boillat A, Boesch A and Kellenberger S. (2006) Trypsin cleaves acidsensing ion channel $1 \mathrm{a}$ in a domain that is critical for channel gating. J Biol Chem 281: 714-22 [PMID:16282326]

79. Waldmann R, Bassilana F, de Weille J, Champigny G, Heurteaux C and Lazdunski M. (1997) Molecular cloning of a non-inactivating proton-gated $\mathrm{Na}+$ channel specific for sensory neurons. J Biol Chem 272: 20975-8 [PMID:9261094]

80. Waldmann R, Champigny G, Bassilana F, Heurteaux C and Lazdunski M. (1997) A proton-gated cation channel involved in acid-sensing. Nature 386: 173-7 [PMID:9062189]

81. Waldmann R, Champigny G, Voilley N, Lauritzen I and Lazdunski M. (1996) The mammalian degenerin MDEG, an amiloride-sensitive cation channel activated by mutations causing neurodegeneration in Caenorhabditis elegans. J Biol Chem 271: 10433-6 [PMID:8631835]

82. Wang JJ, Liu F, Yang F, Wang YZ, Qi X, Li Y, Hu Q, Zhu MX and Xu TL. (2020) Disruption of auto-inhibition underlies conformational signaling of ASIC1a to induce neuronal necroptosis. Nat Commun 11: 475 [PMID:31980622]

83. Wang W, Duan B, Xu H, Xu L and Xu TL. (2006) Calcium-permeable acid-sensing ion channel is a molecular target of the neurotoxic metal ion lead. J Biol Chem 281: 2497-505 [PMID:16319075]

84. Wang YZ, Wang JJ, Huang Y, Liu F, Zeng WZ, Li Y, Xiong ZG, Zhu MX and Xu TL. (2015) Tissue acidosis induces neuronal necroptosis via ASIC1a channel independent of its ionic conduction. Elife 4 [PMID:26523449]

85. Wemmie JA, Taugher RJ and Kreple CJ. (2013) Acid-sensing ion channels in pain and disease. Nat Rev Neurosci 14: 461-71 [PMID:23783197]

86. Wiemuth D, Assmann M and Gründer S. (2014) The bile acid-sensitive ion channel (BASIC), the 
ignored cousin of ASICs and ENaC. Channels (Austin) 8: 29-34 [PMID:24365967]

87. Xiong ZG, Chu XP and Simon RP. (2007) Acid sensing ion channels--novel therapeutic targets for ischemic brain injury. Front Biosci 12: 1376-86 [PMID:17127388]

88. Yang L and Palmer LG. (2014) Ion conduction and selectivity in acid-sensing ion channel 1.J Gen Physiol 144: 245-55 [PMID:25114023]

89. Yoder N and Gouaux E. (2020) The His-Gly motif of acid-sensing ion channels resides in a reentrant 'loop' implicated in gating and ion selectivity. Elife 9 [PMID:32496192]

90. Yoder N, Yoshioka C and Gouaux E. (2018) Gating mechanisms of acid-sensing ion channels. Nature 555: 397-401 [PMID:29513651]

91. Yu Y, Chen Z, Li WG, Cao H, Feng EG, Yu F, Liu H, Jiang H and Xu TL. (2010) A nonproton ligand sensor in the acid-sensing ion channel. Neuron 68: 61-72 [PMID:20920791]

92. Zha XM, Wang R, Collier DM, Snyder PM, Wemmie JA and Welsh MJ. (2009) Oxidant regulated inter-subunit disulfide bond formation between ASIC1a subunits. Proc Natl Acad Sci USA 106: 3573-8 [PMID:19218436]

93. Ziemann AE, Allen JE, Dahdaleh NS, Drebot II, Coryell MW, Wunsch AM, Lynch CM, Faraci FM, Howard 3rd MA and Welsh MJ et al.. (2009) The amygdala is a chemosensor that detects carbon dioxide and acidosis to elicit fear behavior. Cell 139: 1012-21 [PMID:19945383]

94. Ziemann AE, Schnizler MK, Albert GW, Severson MA, Howard MA, Welsh MJ and Wemmie JA. (2008) Seizure termination by acidosis depends on ASIC1a. Nat Neurosci 11: 816-22 [PMID:18536711] 